\title{
COMPARISON OF WORKPLACE BULLYING, DISTRESS LEVEL and SATISFACTION WITH LIFE ON POWER PLANT ENERGY IN INDONESIA
}

\author{
Ika Agustina Wahyuningtias ${ }^{1}$, Sjahrul Meizar Nasri ${ }^{2}$, Dadan Erwandi ${ }^{3}$, Fatma Lestari ${ }^{4}$, \\ Abdul Kadir ${ }^{5}$ \\ Master Program of Occupational Health \& Safety, Faculty of Public Health, Universitas Indonesia ${ }^{1}$ \\ Occupational Health \& Safety Department, Faculty of Public Health, Universitas Indonesia ${ }^{2,3,4,5}$ \\ Disaster Risk Reduction Center, Universitas Indonesia ${ }^{4}$ \\ ika.agustina91@ui.ac.id', dadan@ui.ac.id ${ }^{3}$
}

\begin{abstract}
Bullying does not only occur in the school environment. It can also happen at the workplace. Research related to workplace bullying is still difficult to find in Indonesia, even the existing reports on this topic are barely enough to explain how this phenomenon is handled this country. This study aims to determine and examine the incidence of workplace bullying in the energy sector or the power generation industry by involving seven power plants throughout Indonesia. The design of this study was a cross-sectional study with domicile/work area as independent variables and bullying (total bullying as a negative act), distress level, and satisfaction with life as the dependent variables. 219 workers participated in this study by filling out the Negative Acts Questionnaire-Revised (NAQ-R). The results of the analysis showed that there was no comparison of bullying incidents among the seven power plants $(F=0.71, p$ $=0.135)$ and that the bullying level in these 7 power plants was low (mean= 26.7), with the highest mean was found in Southeast Sulawesi (mean=27.9). This shows that the incidence of bullying in the seven power plants is in the low category, with the highest tendency of bullying seen in the power plant in Southeast Sulawesi. Since workplace bullying correlates with job burnout that will lead to increased number of fatal accident and company losses, it is suggested that some programs that are aimed at controlling the risk cause by bullying should be implemented
\end{abstract}

Keywords $\quad$ : Bullying, Satisfaction with Life, Distress, Psychosocial Hazards, Mental Health

\begin{abstract}
ABSTRAK
Bullying tidak hanya terjadi di lingkungan sekolah namun juga di tempat kerja. Penelitian terkait perundungan di tempat kerja yang terjadi di Indonesia masih sulit ditemukan, bahkan hampir tidak cukup untuk menjelaskan fenomena ini ditangani di Indonesia. Penelitian ini bertujuan untuk mengetahui dan mengkaji kejadian perundungan di tempat kerja (workplace bullying) di sektor energi ataupun industri pembangkit tenaga listrik yang melibatkan tujuh pembangkit listrik di seluruh Indonesia. Penelitian ini merupakan studi potong lintang dengan area kerja sebagai variable bebas dan perundungan di tempat kerja (workplace bullying), tingkat distress dan kepuasan hidup pekerja sebagai variable terikat. Metode pengambilan sampel menggunakan random purposive sampling. 219 tenaga kerja di Industry pembangkit listrik yang ikut berpastisipasi dalam pengisian kuesioner Negative Acts Qustionnaire-Revised (NAQ-R). Hasil analisa menunjukkan bahwa tidak ada perbandingan kejadian perundungan di antara ketujuh pembangkit $(F=0,71, p=0,135)$ dan dari ketujuh pembangkit rata-rata tindak kejadian perundungan berada dalam level rendah (mean=26,7) dengan mean tertinggi yang didapat adalah 27,9 di Sulawesi Tenggara. Hal ini menunjukkan tingkat kejadian perundungan di tujuh pembangkit tenaga listrik tergolong dalam kategori rendah dengan kecenderungan tertinggi pada pembangkit di Sulawesi Tenggara. Karena perundungan di tempat kerja memiliki korelasi terhadap terjadinya kelelahan kerja yang berujung pada meningkatnya kecelakaan fatal dan kerugian yang akan ditanggung oleh perusahaan, peneliti menyarankan beberapa program terkait pengendalian resiko yang diakibatkan kejadian perundungan.
\end{abstract}

Kata Kunci $\quad$ : Bullying, Perundungan, Kepuasan Hidup, Distress, Bahaya Psikososial, Kesehatan Mental. 


\section{INTRODUCTION}

One form of violence in the workplace is workplace bullying/mobbing. Workplace bullying is a complex multicausal and multilevel phenomenon observed in various countries. Workplace bullying is basically a form of behavior that harasses, offends, or removes someone from social life, or negatively affects one's performance (Einarsen, Hoel, Zapf, \& Cooper, 2011). Workplace bullying is also defined as repeated negative behaviors in the form of physical, verbal, or psychological acts that aims to get the effect of fear, distress, or physical harm caused by an imbalanced position where the perpetrator becomes superior than the victim (Akella, 2016) (Arenas, et al., 2016)

Research related to workplace bullying is still very difficult to find in Indonesia and the existing studies even barely enough to explain how this phenomenon is handled in this country. Bullying has been widely researched, but the majority of the studies are performed in school settings or adolescent settings. There has not been any in-depth research on bullying that has been conducted comprehensively in work settings (Silviandari \& Helmi, 2018). Most of the research on bullying conducted in the last decade has come from Europe, Australia, and United States (Sansone \& Sansone, 2015). Research on workplace bullying has been progressing very significantly after the European Journal of Work and Organizational Psychology declared bullying and mobbing in the workplace as a phenomenon that needs to be studied scientifically. Research related to this field is still largely dominated by Stale Einarsen and Hoel from Scandinavia (Silviandari \& Helmi, 2018).

Indonesia already has a law that governs workplace bullying in general, which is Law. No.13/2003 on Manpower that specifically described this phenomenon in Article 86 sub article (1) and Article 169 sub article (1). However, there is no provision that specifically mentions the forms of workplace bullying, as well as the sanctions or ways to overcome it. In addition, bullying is one of the psychosocial risks in the workplace and has received increasing attention from several standardization organizations such as ISO 45001, which was published in March 2018, that explicitly requires companies to refer to this standard in implementing efforts to control, manage, and identify psychosocial hazards.

Rahmadani (Rahmadani, (2016)) quoted that a survey by the Workplace Bullying Institute in 2012 has identified that workplace bullying is caused by a lot of factors, i.e. work environment factors, individual factors, and actions taken against bullying. Work environment and cultural factors that create competitions among employees will lead to an unhealthy condition. Some employees may have a tendency of conducting hyper-aggressive behaviors that may be expressed in bullying. The result of the survey also showed that most companies do not have regulations regarding bullying and, if any, they do not have the capability to stop the behavior.

Workplace bullying can be classified into three categories: (1) Person-related bullying, which includes negative actions aimed at the personality of a person through spreading rumors, verbal abuse, persistent critics, false accusations, and social isolation; (2) Work-related bullying, which is a negative action that leads to one-sided elimination or changes in the work task of the victim, such as extremely severe supervision, giving a task that is beyond the competency of the victim, and giving trivial tasks that do not match with the competency of the victim, and; (3) Physicallyintimidating bullying, which is a direct intimidation to the victim such as screaming at the victim, threatening, or intimidating the victim. Meanwhile, from the perspective of the actor of bullying, workplace bullying can be categorized into three: (1) Downwards bullying, which is a bullying that is done by a worker with a higher 
position to another worker with a lower position, (2) Horizontal bullying, which is an act of bullying that is performed to a worker with the same position level, and (3) Upward bullying, which is a bullying act that is performed by a worker with a lower position to another worker with a higher position (Hidayati, 2016)

In general, the impact of workplace bullying can be classified into two categories: (1) Individual psychological impact and (2) impact on the organization (Hidayati, 2016). In terms of the individual impact, the act of bullying may weaken the mental health of the victim. Leymann (Leymann, 1990) in (Rahmadani, (2016)) stated that workplace bullying leads to social, psychological, psychosocial, psychosomatic, and psychiatric effects to the victim. The victim may experience depression, hyperactivity, psychosomatic symptoms, reduced immunity, and, worse, suicidal thoughts. From the organizational perspective, bullying can increase the risk of the workers, as a part of the organization, to experience fatigue and will reduce productivity (Ertureten, Cemalcilar, \& Aycan, 2013) (Rouse, Gallagher-Garza, Gebhard, Harrison, \& Wallace, 2016) (Barker Steege \& Nussbaum, 2013). Fatigue itself also has an implication on the increase in the number of accidents (Williamson, et al., 2011)and can become the initial cause of fatal accidents (Rohit, Kaiquan, Shiyun, \& Li, 2009) (Ma, Lou, \& Wang, 2010).

Workplace bullying has a negative relationship with workers' mental health (Rahmadani, (2016)). The higher the bullying level is, the lower the mental health status of the workers and vice versa. A study in Turkey that involved employees in public sector discovered the relationship between bullying acts and anxiety, depression, and stress (Gabriele , Leon-Perez, \& Arenas, 2015). Bullying can also trigger health symptoms such as psychosomatic symptoms in the form of headache, eating and sleeping disorders, depression, and anxiety (Yeow, Chin, Ng, \& Yong, 2010) which will increase absenteeism due to illness-related reasons (Gabriele , Leon-Perez, \& Arenas, 2015). Workplace bullying also influence satisfaction with work (Gabriele , LeonPerez, \& Arenas, 2015). A previous study in Australia and Singapore also suggested a negative relationship between bullying and workers' satisfaction, with Australia showing a stronger relationship compared to Singapore. This might be due to the culture of resistance towards social diversity in Australia (Loh, Restubog, \& Zagenczyk, 2010)

The level of negative acts related to workplace bullying can be influenced by the type of job or industry, with some jobs have a higher tendency for negative actions like bullying than others. Jobs that relate to public services and administrative has a higher tendency for bullying at the workplace; thus, bullying can be seen more among government employees. From the perspective of the type of industry, workplace bullying tends to be higher in construction, financial and insurance, manufacture, and engineering industries (Alterman, Luckhaupt, Dahlhamer, Ward, \& Calvert, 2013).

Power generation industry comprises of companies working in electrical field to provide power for the society. To support their activities, power plants employ human resource for maintaining and operating the power generators. The human resource, which is referred to as workers, is hired by the company by prioritizing local people who live in the area where the power plant is operating.

This survey was performed to provide an overview on the negative actions in the form of bullying at the workplace and the difference in the level of bullying as a negative act between each work area. It is also the intention of this survey to identify the differences in the distress level and satisfaction with work. The information gained is expected to inform the company in making policies and anticipating workplace bullying among their workers so that the atmosphere of working will be positive for all members of the organization. 


\section{METHODS}

This study was a quantitative study involving workers who work in the energy sector, or in the power plant industry in particular, whose age was above 17 years old and had already worked in the industry for at least 6 months. The sites for data collection were power plants in seven work areas, i.e. West Java, East Kalimantan, West Nusa Tenggara, East Nusa Tenggara, North Maluku, Southeast Sulawesi, and Papua. The sample method uses random purposive sampling. Number of employees involved as respondents was 225 . The primary data used in this study; the survey participants answered a questionnaire given by the researcher through the electronic link form.

The design of this study was a crosssectional study with domicile/work area as independent variables and bullying (total bullying as a negative act), distress level, and satisfaction with life as the dependent variables. Measurements of the bullying variable, distress level, and satisfaction with life dimensions were performed using the Negative Acts Questionnaire-Revised (NAQ-R) as developed by Einarsen, Hoel \& Notelaers (Einarsena, Hoel, \& Notelaersa, 2009 ).

Workplace bullying was defined to the participants as repeated behaviors that insult, humiliate, sabotage, intimidate, or negatively affect someone's work with the emergence of imbalance power. This type of behavior is usually repeated from time to time. The measurement of bullying was performed using the NAQ-R (Einarsena, Hoel, \& Notelaersa, 2009 ). This questionnaire consisted of 22 items that reflect unpleasant acts or behavior at the workplace. The participants were asked to assess how far they had received negative actions during the last 6 months. The scoring used for the 22 items were the Likert scale with a 5-point format $(1=$ Never, $2=$ Sometimes, 3 = Every Month, $4=$ Every Week, 5 = Daily).
For the measurement of the distress level, the Kessler Psychological Distress Scale was used. This scale consists of 10 items regarding the experience of depression and anxiety symptoms. Each question was also scored using the Likert scores with Never, Rarely, Sometimes, Almost Always, and Always options (Kessler \& Mroczek, 1994) in (Dollard, Dormann, Michelle, \& Escartín, 2017).

In this study, the Satisfaction with Life Scale (SwLS) was used to measure the level of satisfaction of the respondent towards their life using a cognitive approach. Respondents answered 5 questions using the 7-point Likert scale of Strongly Disagree, Disagree, A Bit Disagree, Neutral, A Bit Agree, Agree, and Strongly Agree (Diener, Emmons, Larsen, Griffin, \& Sharon, 1985) in (Pavot \& Diener, 2008).

A total of 225 questionnaires were distributed to the workers; however, only $97.3 \%$, or 219 respondents, returned the questionnaire with complete data. The data collection was performed from September 15 to December 31, 2020 by including all permanent, contract, and contractor workers who worked in the seven power plants for a minimum of six months as the study population.

The validity and reliability of the instruments used in this study refers to the validity and reliability testing in a study by Erwandi (Erwandi, 2020) under the title of "Identification of Workplace Bullying in Indonesia". In their study, the scores for the validity and reliability of the Negative action (bully) $(\mathrm{N}=3140)$ were $0.43-0.60$ and 0.897 , respectively. The same scores for psychological condition (distress) were 0.46 - 0.73 and 0.881 , while the validity and reliability scores for satisfaction with life were $0.34-0.76$ and 0.841 , respectively.

Item discrimination power test in this study was performed using analysis of variance of 2 or more means (ANOVA or analysis of variance). One of the assumptions of ANOVA test is that the variance of each group should be the same and to know whether this assumption 
applied to the data, the variance homogeneity testing was performed by comparing the $-\mathrm{p}$ (sig.) value to alpha $=0.05$ value. When a significant difference was identified, the Post-Hoc Multiple Comparison using Scheefe method was performed to see which groups were different.

\section{RESULTS}

Participants

Table 1 Characteristic of Participants from 7 power plants in Indonesia on 2020.

\begin{tabular}{|c|c|c|}
\hline Respondent & Frequency & $\begin{array}{l}\text { Percentag } \\
\text { e }\end{array}$ \\
\hline \multicolumn{3}{|l|}{ Gender } \\
\hline Male & 203 & 92.7 \\
\hline Female & 16 & 7.3 \\
\hline \multicolumn{3}{|l|}{ Age } \\
\hline$<25$ years old & 36 & 16.4 \\
\hline 25-29 years old & 65 & 29.7 \\
\hline $30-34$ years old & 43 & 19.6 \\
\hline $35-40$ years old & 34 & 15.5 \\
\hline$>40$ years old & 41 & 18.7 \\
\hline \multicolumn{3}{|l|}{ Education } \\
\hline Elementary School & 1 & 0.5 \\
\hline Junior High School & 4 & 1.8 \\
\hline Senior High School & 62 & 28.3 \\
\hline Diploma 3 & 43 & 19.6 \\
\hline Diploma & 108 & 49.3 \\
\hline 4/Undergraduate & 1 & 0.5 \\
\hline Master & & \\
\hline \multicolumn{3}{|l|}{ Service Year } \\
\hline$<3$ year & 158 & 72.1 \\
\hline 4-6 year & 20 & 9.11 \\
\hline $7-10$ year & 18 & 8.2 \\
\hline$>10$ year & 23 & 10.5 \\
\hline \multicolumn{3}{|l|}{ Domicile } \\
\hline West Java & 44 & $20.1 \%$ \\
\hline East Kalimantan & 30 & $13.7 \%$ \\
\hline North Maluku & 21 & $9.6 \%$ \\
\hline Papua & 43 & $19.6 \%$ \\
\hline South-east Sulawesi & 27 & $12.3 \%$ \\
\hline West Nusa Tenggara & 31 & $14.2 \%$ \\
\hline East Nusa Tenggara & 23 & $10.5 \%$ \\
\hline \multicolumn{3}{|l|}{ Position } \\
\hline $\begin{array}{l}\text { Implementer/Opera } \\
\text { tor/Admin }\end{array}$ & 73 & $33.3 \%$ \\
\hline Staff & 23 & $10.5 \%$ \\
\hline Supervisor & 58 & $26.5 \%$ \\
\hline Assistant Manager & 3 & $1.4 \%$ \\
\hline Manager & 9 & $4.1 \%$ \\
\hline Others & 53 & $24.2 \%$ \\
\hline
\end{tabular}

\begin{tabular}{lll}
$\begin{array}{l}\text { Employment } \\
\text { Status }\end{array}$ & & \\
\hline Permanent & 138 & $63 \%$ \\
Employee & 53 & $24.2 \%$ \\
Contract & 28 & $12.8 \%$ \\
Employee & & \\
Third-party & & \\
employee & & \\
(outsourcing) & & \\
\hline
\end{tabular}

Based on table 1, male workers comprised the majority of the respondents with $92.7 \%$ with women only contributed $7.3 \%$. This is not surprising because the power plant industry sector is still dominated by men because more men have technical competencies in relation to machinery compared to women. Most of the respondents were in the productive age of 25-29 years old $(29.7 \%)$ with most of them had Diploma 4 or Undergraduate education (49.3\%). The most dominant position characteristics of the respondent was Operator/Implementer (33.3\%), followed by permanent employees (63\%) who had been working for less than 3 years $(72,1 \%)$. Most of the respondents came from West Java (20.1\%), followed by Papua $(19.6 \%)$ and West Nusa Tenggara (14.2\%)

Distribution of Workplace Bullying Acts, distress level and satisfaction with life among workers on 7 powerplant area

Table 2 Distribution of the mean value of all workplace bullying variables from 7 power plants in Indonesia on 2020.

\begin{tabular}{llll}
\hline \multirow{2}{*}{ Area } & \multicolumn{2}{l}{$\begin{array}{l}\text { Total } \\
\text { Bullying }(\mu=26.7)\end{array}$} \\
\cline { 2 - 4 } & Mean & $F$ & $p$ \\
\hline West Java & 27.7 & 0.717 & 0.636 \\
East Kalimantan & 24.9 & & \\
North Maluku & 26.1 & & \\
Papua & 26.3 & & \\
South-east Sulawesi & 27.9 & & \\
West Nusa Tenggara & 26.4 & & \\
East Nusa Tenggara & 26.6 & & \\
\hline West Java & 1.16 & 1.222 & 0.296 \\
East Kalimantan & 1.10 & & \\
North Maluku & 1.10 & & \\
Papua & 1.26 & & \\
South-east Sulawesi & 1.22 & & \\
West Nusa Tenggara & 1.23 & & \\
East Nusa Tenggara & 1.43 & & \\
\hline
\end{tabular}




\begin{tabular}{|c|c|c|c|}
\hline \multirow{2}{*}{ Area } & \multicolumn{3}{|c|}{ Distress Level } \\
\hline & Mean & $F$ & $p$ \\
\hline West Java & 15.41 & 0.584 & 0.743 \\
\hline East Kalimantan & 15.23 & & \\
\hline North Maluku & 15.43 & & \\
\hline Papua & 15.07 & & \\
\hline South-east Sulawesi & 14.44 & & \\
\hline West Nusa Tenggara & 14.77 & & \\
\hline East Nusa Tenggara & 16.91 & & \\
\hline \multirow{2}{*}{ Area } & \multicolumn{3}{|c|}{ Satisfaction with Life } \\
\hline & Mean & $F$ & $p$ \\
\hline West Java & 3.39 & 1.493 & .182 \\
\hline East Kalimantan & 3.10 & & \\
\hline North Maluku & 2.57 & & \\
\hline Papua & 3.37 & & \\
\hline South-east Sulawesi & 2.63 & & \\
\hline West Nusa Tenggara & 2.97 & & \\
\hline East Nusa Tenggara & 2.87 & & \\
\hline
\end{tabular}

Based on the result of the study, which is referred to in table 2, the incidence of bullying based on the total negative act of bullying in the power plant industry energy sector was included in the low category (mean=26.7), with the highest mean distribution found in the Southeast Sulawesi area $($ mean $=27.9)$. Meanwhile, the level of feeling bullied among workers in this sector also shows a low score with the highest mean identified in East Nusa Tenggara (mean=1.43), with most workers answered with "Rarely" to "Yes, but rarely". It is also apparent in table 3 that $84 \%$ of the workers stated that they had never felt bullied while $11.4 \%$ stated that they sometimes felt that they received negative actions related to bullying. The remaining, i.e. $4.1 \%$, stated that they felt that they were bullied in monthly basis while $0.5 \%$ felt that they were bullied in weekly basis.

For the distress level of workers working in this sector, the result of this study demonstrated a low level of distress with, according to the converted results, the highest mean was seen in East Nusa Tenggara of 16.9 while the rest was below this mean. When converted into the categories in Kessler Psychological Distress Scale, where a total distress soccer of less than 20 is deemed to be low, it can be interpreted that the work distress level in this study was low and the mental health of the workers was good. The prevalence of the distress level of workers in this sector, as seen in table 3 , showed that $79.9 \%$ of the workers were in a good mental health condition while $14.2 \%$ experienced mild mental disorder and the remaining experienced moderate mental disorder $(5 \%)$ and severe mental disorder $(0.9 \%)$.

The level of satisfaction with life for workers in this sector shows that most of the workers felt quite satisfied with their life, with the lowest satisfaction level identified in the work area of West Java with the highest mean compared to other areas (3.39). The prevalence of satisfaction with life among workers in the power plant energy sector, as referred in table 3 , stated that $37 \%$ of workers felt satisfied with their life while $21.9 \%$ declared that they were slightly satisfied. Meanwhile $14.2 \%, 10 \%$, $8.7 \%, 6.8 \%$, and $1.4 \%$ felt they were slightly dissatisfied, extremely satisfied, neutral, dissatisfied, and extremely dissatisfied with their life, respectively.

Table 3. Prevalence of All Variables of workplace bullying from 7 power plants in Indonesia on 2020.

\begin{tabular}{|c|c|c|c|}
\hline Item & Category & Frequency & $\begin{array}{l}\text { Percentage } \\
(\%)\end{array}$ \\
\hline \multirow{4}{*}{$\begin{array}{l}\text { Feeling } \\
\text { Bullied } \\
\text { (B22) }\end{array}$} & Never & 184 & 84.0 \\
\hline & Sometime & 25 & 11.4 \\
\hline & $\begin{array}{l}\text { Every } \\
\text { Month }\end{array}$ & 9 & 4.1 \\
\hline & $\begin{array}{l}\text { Every } \\
\text { Week }\end{array}$ & 1 & 0.5 \\
\hline \multirow{4}{*}{$\begin{array}{l}\text { Distress } \\
\text { Level }\end{array}$} & $\begin{array}{l}\text { Mentally } \\
\text { Well }\end{array}$ & 175 & 79.9 \\
\hline & $\begin{array}{l}\text { Mid mental } \\
\text { disorder }\end{array}$ & 31 & 14.2 \\
\hline & $\begin{array}{l}\text { Moderat } \\
\text { mental } \\
\text { disorder }\end{array}$ & 11 & 5.0 \\
\hline & $\begin{array}{l}\text { Severe } \\
\text { mental } \\
\text { disorders } \\
\end{array}$ & 2 & 0.9 \\
\hline \multirow{5}{*}{$\begin{array}{l}\text { Satisfaction } \\
\text { With Life }\end{array}$} & $\begin{array}{l}\text { Extremely } \\
\text { Satisfied }\end{array}$ & 22 & 10.0 \\
\hline & Satisfied & 81 & 37.0 \\
\hline & $\begin{array}{l}\text { Slightly } \\
\text { Satisfied }\end{array}$ & 48 & 21.9 \\
\hline & Neutral & 19 & 8.7 \\
\hline & $\begin{array}{l}\text { Slightly } \\
\text { Dissatisfied }\end{array}$ & 31 & 14.2 \\
\hline
\end{tabular}




\begin{tabular}{llll}
\cline { 2 - 4 } Satisfaction & Dissatisfied & 15 & 6.8 \\
\cline { 2 - 4 } With Life & $\begin{array}{l}\text { Extremely } \\
\text { Dissatisfied }\end{array}$ & 3 & 1.4 \\
& & \\
\hline
\end{tabular}

Furthermore, we reviewed whether there is a significant difference in the bullying events and other variable in each work area. Through the analysis using the ANOVA (Analysis of Variance), the first step was to do normality testing with the result of the SE-Skewness divided by the Skewness for all variables of $<3.0$, so data can be stated as normal. After that, a homogeneity testing was performed and results were gained for bullying event (sig=0.135), feeling of being bullied ( $\operatorname{sig}=0.29)$, distress level $(\operatorname{sig}=0.19)$, and satisfaction with life level (sig=0.41). Since the sig- values for variance homogeneity for all variables were $>0.05$, data were declared as homogeneous. The next step was to test for the mean variance for more than 2 variables using ANOVA. The results, as presented in table 2, demonstrated the following results of the variance testing for total variable, as listed in table 2: bullying act $(F=0.717, p=0.636)$, feeling bullied $(F=1.222, \quad p=0.296), \quad$ distress level $(F=0.584, p=0.743)$, and satisfaction with life $(F=1.493, \quad p=0.182)$. The Null hypothesis (Ho) was no difference in bullying event, feeling bullied, distress level, and satisfaction with life among the seven work areas of the power plant while the alternative hypothesis (Ha) was there was differences between the bullying event, feeling bullied, distress level, and satisfaction with life among the seven work areas of the power plant. Meanwhile, to test the hypothesis that there was a difference in the variables, a p-value from the result of the ANOVA was used and it was concluded that all variables had a $p$-value of $p>0.05$ that the Null Hypothesis (Ho) can be accepted that there was no difference in the level of workplace bullying in the work areas, which was also true for feeling bullied, distress level, and satisfaction with life.

\section{DISCUSSION}

The aim of this study was to identify the differences in the bullying event, distress level, and satisfaction with life among workers in the power plant sector located in seven provinces in Indonesia. In addition, this study also analyzed the prevalence of bullying events, distress level, and satisfaction with life among workers in the seven work areas of power plant sector. Based on the analysis of variance result, it is concluded that there is no difference in the bullying level in the seven work areas (workplace bullying), which is also true for feeling bullied, distress level, and satisfaction with life.

\section{Workplace Bullying Level}

Although it is concluded above that most of the workers in the seven power plants never experience negative actions related to workplace bullying $(84 \%)$, there are still reports of bullying experience or becoming the target of workplace bullying from some workers. Around $4.1 \%$ workers have experienced negative actions related to bullying in a monthly basis and $0.5 \%$ of workers experienced negative actions related to bullying in weekly basis.

We elaborated the highest number of cases from each category of bullying acts that are divided into three types: workrelated bullying, physically intimidating bullying, and person-related bullying. It was reported that (1) the highest number of negative actions for work-related bullying is seen in the form of being ordered to do works that are in the lower level than the competence of the workers (daily, $1.8 \%$; monthly, $1.4 \%$; and weekly, $0.9 \%$ ), (2) the most frequent act of physically intimidating bullying is that workers have an experience of being shouted at or becoming the target of spontaneous anger (monthly, 1.4\%; and daily, $0.5 \%$ ), and (3) the highest number of person-related bullying act takes the form of critics that are given persistently related to their efforts and works (daily, 1.4\%; monthly, $0.9 \%$; and weekly, $0.5 \%$ ) 
Of the seven work areas of power plant, Southeast Sulawesi has a higher tendency for negative actions in the form of bullying compared to other work areas. However, this is in contrast with the result of feeling bullied, where workers in East Nusa Tenggara have a tendency for feeling bullied than other work areas. Even though the level of bullying in the seven work areas of power plant is low and no difference is seen among these areas, it is assumed that this result is influenced by differences in perception, culture, gender, and personal values. This statement is supported by a previous study that culture, including the mindset, background, education status, ethnicity, gender, and race can become the dominant antecedents in workplace bullying issue in workplaces in Asia (Yusop, Dempster, \& Stevenson, 2014). Furthermore, the level of workplace bullying is often considered to have a link with work and organizational factors (Salin, 2015). Some studies also mentioned the relationship between individual factors such as personality or demographic factors (culture, educational background, age, and others) with the tendency of someone becoming a target of bullying (Einarsen, Hoel, Zapf, \& Cooper, 2011) (NOTELAERS, VERMUNT, BAILLIEN, EINARSEN1, \& WITTE, 2011).

Culture has a strong influence in predicting bullying event in a diverse group (Khan, 2014). Bullying is a socially developed phenomenon (Lewis, 2003) and the cognitive scheme and motivation mechanism are represented in the cultural orientation to develop perception and reaction to bullying (Agarwal \& Gupta, 2016). Workers as individuals coming from different culture and background tend to have different perception on workplace bullying so it is assumed that this difference will influence the reported workplace bullying level against the factual bullying (Leng \& Yazdanifard, 2014). The organizational culture is the one that shape the behaviors of the workers (Young-Ran \& Jeong-Won , 2016), including the behavior towards workplace bullying. If in the workplace there is a perception that negative actions in the form of bullying are normal as a part of the work (Yıldız \& Tüzüntürk, 2008), tolerable (Gabriele, Leon-Perez, \& Arenas, 2015), considered to be the type of communication between superiors to subordinates to give motivation (Mayhew, et al., 2004) and a part of a work culture that is oriented towards performance by setting aside the orientation to workers (Power, et al., 2013), the tendency of a lower reported bullying in the workplace will be higher.

Although workplace bullying may happen to workers from all genders (Namie, 2003), the difference in the proportion of perpetrators and victim in bullying in gender context is observed and influence the difference in the perception and level of reported bullying acts. Since the majority of respondents in this study are men $(92.7 \%)$, it should be taken into consideration that male workers more often experience predatory bullying where the negative treatment makes the victim becomes the scapegoat of a mistake, by giving tasks that are beyond the victim's capability and responsibility, or by giving specific nickname to the victim. On the other hand, the male workers have an individual perception that the negative actions are not considered as workplace bullying but a form of responsibility, way of communicating in the work environment (Rahmadani, (2016)) or just a tolerable joke (Roland \& Munthe, 1989). According to most male workers, reporting workplace bullying and exposing the actions to public will only add problems. Furthermore, male workers have a trait of masculinity and consider bullying as a test for the masculinity level of a man (O'Donnell \& MacIntosh, 2016).

\section{Worker Distress Level}

Overall, the distress level among workers in the seven power plants is low (Kessler distress scale<20) (Kessler \& Mroczek, 1994) and most workers have good mental health status $(79.9 \%)$ with workers in East Nusa Tenggara Power plan 
have a tendency to have a higher distress level compared to other power plants. Based on the Kessler Distress Scale (Kessler \& Mroczek, 1994)used, the most frequent complaints from the respondents are workers often need more efforts (hard work) in achieving everything. The low level of distress and the different level in distress are due to the difference in the risk level between male and female workers. Male workers tend to have a higher mental health degree than female workers (Gabriele , Leon-Perez, \& Arenas, 2015) (Nielsen \& Einarsen, 2012). There is a perception that naming or becoming the object of jokes by fellow workers is a type of socialization and masculinity testing among men (Rahmadani, (2016)) which, surely, does not create a distress effect on workers in the seven power plants where the majority of workers are men. Men often delay or even do not report complaint regarding their mental health because they are afraid of being seen as week, not man enough, and not masculine (Courtenay, 2000) (Messner, 1997) (Sabo, 2000). Educational background also has an impact on the distress level of the workers. Workers with higher education are considered to have a higher coping ability against stressors so work-related stress that is caused by, among others, bullying is also low in this group (Wati, 2013) (Irkhami, 2015).

The result of this study strengthens the statement that the low bullying level relates to the low distress level in the seven power plants. Even though we do not perform correlation test in this study, this statement is supported by a previous study that negative action in the form of bullying correlates negatively with mental health (Gabriele , Leon-Perez, \& Arenas, 2015) that the higher the workplace bullying level is, the lower the mental health status of the workers or the higher the bullying level in the workplace that then leads to a higher distress level among workers. The same is true in this study, where the low bullying level is reflected in the low level of distress among workers.
Satisfaction with life level among workers overall, the workers in the seven power plant areas are adequately satisfied with their life (37\%). Even though the level of satisfaction of life among workers in the seven power plants is in the satisfactory category, a lower level is seen among workers who work in the power plant in West Java which may relate to the difference in salary and living costs, working environment, types of work, and leadership (Luthans, 2005). In view of the fact that the West Java power plant has a high-power capacity with a higher number of power generators to operate and longer work hours as well as more complex tasks caused by the location that is on the most crowded island in the country, the satisfaction with life of the workers might be influenced by those factors.

Overall, the satisfaction with life level among workers in the seven power plants is still included in the category of quite good, which surely links to the low level of workplace bullying in these power plants. Just as stated in the previous study, workplace bullying has a negative relationship with workers' satisfaction with life (Gabriele , Leon-Perez, \& Arenas, 2015). It is concluded that when the workplace bullying level is low, the satisfaction with life will be high among workers as demonstrated in this study.

Workplace bullying can affect worker's mental health regardless whether the action is labelled as such or not (Vie, Glasø, \& Einarsen, 2011). Workplace bullying also affects employee's health and welfare (Shahbazi, Naami, \& Aligholizadeh, 2013) that specific attention should be given to reduce the impact on the worker productivity level (Rouse, Gallagher-Garza, Gebhard, Harrison, \& Wallace, 2016) and the possible loss for the company (Aleassa $\&$ Megdadi, 2014). Workers who experience bullying also experience higher job burnout due to work-related stress and stress caused by interpersonal relationship (Young-Ran \& Jeong-Won , 2016). Job burnout that increases due to workplace bullying will 
increase the risks in occupational safety (Williamson, et al., 2011). If the condition occurs in a risk work condition, it may become the initial cause of fatal accident (Rohit, Kaiquan, Shiyun, \& Li, 2009) (Ma, Lou, \& Wang, 2010).

Although the result of data processing in this study shows that the level of bullying in the seven powerplants is low, it is necessary to note that workplace bullying cannot be considered as non-existence because the result of the descriptive data show that there are still bullying felt by and happens to the workers. Hence, we suggest that the company can manage this risk from upstream to downstream using a tripartite approach. This may include policies that protect workers against bullying actions and interventions such as programs that involve compliance and sanction, or a support program for workers who are victims of bullying, including those who have mental disorder complaints. Company's organizational culture and understanding of the danger and the management of bullying needs to be reviewed and then developed in the company. Specifically, from the result of the NAQ-R survey, it is apparent that workers feel that they are told to do works that are above their ability or competency that they feel they need to put more efforts to do the work. In this case, we suggested that organization should make changes by providing or review the task distribution for workers as stated in the job description, by adjusting the organizational structure to the workers' competencies or by adding the number of workers for the task. Workers' capacity should be built by providing training and coaching, as well as periodic two-way discussion.

In general, workers feel that their mental health is good; however, there are some workers who think that they are experiencing low, moderate, or severe mental health disorders. Respondents who show a tendency to give a response of "Almost Always" and "Always" to this item should undergo further assessment according to medical referral. Meanwhile, the respondents with the response of "Rarely" or "Sometimes" need to receive earlier intervention in the form of information regarding promotive program on mental health awareness as a strategy to prevent future mental health problems (Kessler \& Mroczek, 1994). In this case, we suggest that a health program that focuses on stress management, including work-related stress prevention, should be developed.

\section{CONCLUSION}

It is concluded that, in overall, the bullying level in the seven power plants under study is in the low level and there is no difference in the level of bullying events. In addition, most of the workers do not experience bullying, which is also reflected in the low level of distress and high satisfaction with life among workers. Since workplace bullying correlates with job burnout that will lead to increased number of fatal accident and company losses, it is suggested that some programs that are aimed at controlling the risk cause by bullying should be implemented. With the fact that the survey shows several reports of bullying from the respondents, albeit small, this type of program is necessary. It is our expectation that this study can be used as the reference for interventions by the company in this issue. Insights on the context and company's environment are also needed to develop a well-targeted, economical, time savvy, and well-directed program. In addition, it is also expected that this study may contribute to the development of the theoretical concept in future studies.

\section{ACKNOWLEDGEMENT}

The authors would like to thank for three companies (Power Generation) Workers and Contractor that participated in our study, Occupational Health and Safety Department, Faculty of Public Health, Universitas Indonesia (UI) and Disaster Risk Reduction Center UI for the support during completing this study 


\section{REFERENCE}

Agarwal, U. A., \& Gupta, R. K. (2016). Examining the Nature and Effects of Psychological Contract: Case Study of an Indian Organization. Thunderbird International Business Review, 60(2).

Akella, D. (2016). Workplace Bullying: Not a Manager's Right? Journal of Workplace Rights, 1-10.

Aleassa, H., \& Megdadi, O. (2014). Workplace Bullying and Unethical Behaviors: A Mediating Model. nternational Journal of Business and Management; 9(3).

Alterman, T., Luckhaupt, S. E., Dahlhamer, J. M., Ward, B. W., \& Calvert, G. M. (2013). Prevalence rates of work organization characteristics among workers in the U.S.: data from the 2010 National Health Interview Survey. Am J Ind Med, 56(6), 647659.

Arenas, A., Giorgi, G., Montani, F., Mancuso, S., Perez, J., Mucci, N., \& Arcangeli, G. (2016). Workplace Bullying in a Sample of Italian and Spanish Employees and Its Relationship with Job Satisfaction, and Psychological Well-Being. Frontiers in Psychology, 6.

Barker Steege , L. M., \& Nussbaum, M. A. (2013). Dimensions of Fatigue as Predictors of Performance: A Structural Equation Modeling Approach Among Registered Nurses. IIE Transactions on Occupational Ergonomics and Human Factors, 1(1), 16-30.

Courtenay, W. H. (2000). Constructions of masculinity and their influence on men's well-being: a theory of gender and health. Social Science \& Medicine, 50(10), 1385-1401.

Diener, Emmons, E., Larsen, R. A., Griffin, R. J., \& Sharon. (1985). The Satisfaction With Life Scale.
Journal of Personality Assessment, 49(1), 71-75.

Dollard, M. F., Dormann, C., M. R., \& Escartín, J. (2017). Psychosocial safety climate (PSC) and enacted PSC for workplace bullying and psychological health problem reductio. EUROPEAN JOURNAL OF WORK AND ORGANIZATIONAL PSYCHOLOGY, 26(6), 844-857.

Einarsen, S., Hoel, H., Zapf, D., \& Cooper, C. L. (2011). The concept of bullying and harassment at work: The European tradition. Bullying and harassment in the workplace: Developments in theory, research, and practice, 2, 3-40.

Einarsena, S., Hoel, H., \& Notelaersa, G. (2009 ). Measuring exposure to bullying and harassment at work: Validity, factor structure and psychometric properties of the Negative Acts QuestionnaireRevised. Work \& Stress, 23 (1), 2444.

Ertureten, A., Cemalcilar, Z., \& Aycan, Z. (2013). The Relationship of Downward Mobbing with Leadership Style and Organizational Attitudes. J Bus Ethics , 205-216.

Erwandi, D. (2020). Identification of Workplace Bullying in Indonesia. Depok: Universitas Indonesia .

Gabriele , G., Leon-Perez, J., \& Arenas, A. (2015). Are Bullying Behaviors Tolerated in Some Cultures? Evidence for a Curvilinear Relationship Between Workplace Bullying and Job Satisfaction Among Italian Workers. Journal of Business Ethics, 131(1), 227-237.

Gredler, G. R. (2003). In Bullying at school: What we know and what we can do. Maden: Black Well Publishing.

Hidayati, L. (2016). PEMBULIAN DI TEMPAT KERJA DALAM KONTEKS ASIA- Workplace Bullying in Asia Context. Seminar 
Nasional dan Gelar Produk SENASPRO. Malang.

Irkhami, F. (2015). Hubungan Tipe Kepribadian dan Stresor Lingkungan Kerja dengan Stres Kerja Pada Penyelam di PT. Advanced Offshore services. Surabaya.: Universitas Airlangga.

Kessler, R., \& Mroczek, D. (1994). Final version of our non-specific psychological distress scale. Ann Arbor, MI: Survey Research Center of the Institute for Social Research. University of Michigan.

Khan, S. N. (2014). Impact of Hofstede's Cultural Dimensions on Subordinate's Perception of Abusive Supervision. International Journal of Business and Management; 9(12), 239-251.

Leng, C. Z., \& Yazdanifard, R. (2014). The Relationship between Cultural Diversity and Workplace Bullying in Multinational Enterprises. Global Journal of Management And Business Research, 14 (6-A).

Lewis, D. (2003). Voices in the social construction of bullying at work: exploring multiple realities in further and higher education. International Journal of Management and Decision Making, 4 (1 ), 65-81.

Leymann, H. (1990). Mobbing and Psychological Terror at Workplaces. Violence and Victims, 5(2), 119-126.

Loh, J., Restubog, S. L., \& Zagenczyk, T. J. (2010). Consequences of workplace bullying on employee identification and satisfaction among Australians and Singaporeans. Journal of CrossCultural Psychology, 41(2), 236252.

Luthans, F. (2005). Organizational behavior. 10th edition. Boston,: McGraw Hill Irwin.

Ma, Y., Lou, Y., \& Wang, Y. (2010). Road Traffic Accidents Model and Its Application Based on Driver's SelfMistakes. JOURNAL OF TRANSPORTATION SYSTEMS
ENGINEERING

AND

INFORMATION

TECHNOLOG, 10(4), 101-105.

Mayhew, C., McCarthy, P., Chappell, D., Quinlan, M., Barker, M., \& Sheehan, M. (2004). Measuring the extent of impact from occupational violence and bullying of traumatised workers. mployee Responsibilities and Rights Journal, 16(3), 117-134.

Messner, M. A. (1997). Politics of Masculinities: Men in Movements (Gender Lens Series). California: SAGE.

Namie, G. (2003). Workplace bullying: Escalated incivility. Ivey Business Journal: Improving the Practice of Management.

Nielsen, M., \& Einarsen, S. (2012). Outcomes of workplace bullying: ameta-analytic review. Work Stress , 26(4), 309-332.

NOTELAERS, G., VERMUNT, J. K., BAILLIEN, E., EINARSEN1, S., \& WITTE, H. D. (2011). Exploring Risk Groups Workplace Bullying with Categorical Data. Industrial Health, 49(1), 73-88.

O'Donnell, S. M., \& MacIntosh, J. A. (2016). Gender and Workplace Bullying: Men's Experiences of Surviving Bullying at Work. Qual Health Res, 26(3), 351-366.

Pavot, W., \& Diener, E. (2008). The Satisfaction With Life Scale and the emerging. The Journal of Positive Psychology, 3(2), 137-152.

Power, J. L., Brotheridge, C. M., Blenkinsopp, J., Bowes-Sperry, L., Bozionelos, N., Buzady, Z., . . . Mathew, R. (2013). Acceptability of workplace bullying: a comparative study on six continents. In: Journal of Business Research. , 66(3), 374380.

Rahmadani, R. ((2016)). Pengaruh Bullying di Tempat Kerja terhadap Mental Health dan Kepuasan Kerja pada divisi after sales PT XYZ. Thesis 
Fakultas Ekonomi dan Bisnis.Universitas Indonesia.

Rohit, T., Kaiquan, S., Shiyun, S., \& Li, X. (2009). A novel auditory workingmemory vigilance task for mental fatigue assessment. Safety Science, 47, 967-972.

Roland, E., \& Munthe, E. (1989). Bullying (1989): An International Perspective. Routledge.

Rouse, L. P., Gallagher-Garza, S., Gebhard, R. E., Harrison, S. L., \& Wallace, L. S. (2016). Workplace Bullying Among Family Physicians: A Gender Focused Study. Journal of Women's Health, 25(9), 882-888.

Sabo, D. (2000). Men's Health Studies: Origins and Trends. Journal of American College Health , 49(3).

Salin, D. (2015). Risk factors of workplace bullying for men and women: the role of the psychosocial and physical work environment. Scand J Psychol, 56(1):), 69-77.

Salmivalli, C. (2010). Bullying and the peer group: A review. Aggression and Violent Behavior, Volume 15(Issue 2), Pages 112-120.

Sansone, R. A., \& Sansone, L. A. (2015). WORKPLACE BULLYING: A Tale of Adverse Consequences. Innovations in CLINICAL NEUROSCIENCE , 12, 32-37.

Shahbazi, G., Naami, A., \& Aligholizadeh, S. (2013). An Empirical Study of the Relationship Between Three Components of Paternalistic Leadership and Workplace Bullying: The Case of an Iranian Bank. World Applied Sciences Journal, 22(12), 1814-1821.

Silviandari, I. A., \& Helmi, A. F. (2018). Bullying di Tempat Kerja di Indonesia - Workplace Bullying on Indonesia. Buletin Psikologi , 26(2), 137-145.

Vie, T. L., Glasø, L., \& Einarsen, S. (2011). Health outcomes and self-labeling as a victim of workplace bullying.
Journal of Psychosomatic Research, 70(1), 37-43.

Wati, D. (2013). Hubungan Antara Individual Arena dan Work Arena dengan Stres Kerja Pada Pekerja Pembuatan Offshore Pipeline and Mooring Tower (EPC3) Proyek Banyu Urip di PT. Rekayasa Industri, Serang - Banten Tahun 2013. Jakarta: Universitas Islam Negeri Syarif Hidayatullah.

Williamson, A., Lombardi, D. A., Folkard, S., Stutts, J. S., Courtney, T. K., \& Connor, J. L. (2011). The link between fatigue and safety. Accident; Analysis and Prevention, 43(2), 498-515.

Yeow, J. A., Chin, T. S., Ng, P. K., \& Yong, W. Y. (2010). THE CAUSES OF WORKPLACE BULLY IN SMES. GLOBAL CONFERENCE ON SME AND ENTREPRENEURSHIP. Malaysia.

Y1ldız, S., \& Tüzüntürk, S. (2008). Workplace Bullying in Turkey: Prevalence Among Private Sector Employees. Rivista di Psicologia del Lavoro e dell' Organizzazzione, 14(2).

Young-Ran, Y., \& Jeong-Won, H. (2016). Effect of Nurses' Organizational Culture, Workplace Bullying and. International Journal of Bio-Science and Bio-Technology, 8(1), 372-380.

Yusop, Y. M., Dempster, M., \& Stevenson, C. (2014). Understanding inappropriate behaviour: harassment, bullying and mobbing at work in Malaysia. Procedia-Social and Behavioral Sciences, 127, 179183. 